๑ Entomologica Fennica. 8 July 1997

\title{
Parasitism of Stylops (Strepsiptera, Stylopidae) in poly- and oligolectic Andrena hosts (Hymenoptera, Apoidea)
}

\author{
Antti Pekkarinen
}

Pekkarinen, A. 1997: Parasitism of Stylops (Strepsiptera, Stylopidae) in polyand oligolectic Andrena hosts (Hymenoptera, Apoidea). - Entomol. Fennica 8: 109-111.

The taxonomic status of many Stylops species described often on the basis of poor female characters is problematic and host specifity of these dubious species is largely unsettled. In Germany and Finland, oligolectic Andrena species were not observed to be parasitized more frequently by Stylops than polylectic ones. The result does not support several coexisting Stylops species with strict host specifity.

Antti Pekkarinen, Department of Ecology and Systematics, P. O. Box 17, FIN-00014 University of Helsinki, Finland

Received 25 August 1996, accepted 21 May 1997

\section{Introduction}

Strepsiptera are endoparasites of other insects. The males are free living and winged, while females are wingless and, except in one family, also legless and do not leave the host. Stylops species are parasites of many species of Andrena. Species delimitation of parasites is problematic when populations on different hosts are slightly different (Mayr \& Ashlock 1991), and a great number of Stylops species have been described on the basis of poor characters in female cephalothorax (e.g. Luna de Carvalho 1974, Kifune \& Hirashima 1985, Kifune \& Maeta 1990). The morphology of males is much more suitable for taxonomic comparisons than the few structures visible on the females. However, males have been found quite rarely and males of most described species are unknown.

Kinzelbach (1978) listed 55 described species of Stylops and 161 species of Andrena as hosts of Stylops from the western Palaearctic area, but he preliminarily regarded all the described species as synonyms of Stylops melittae Kirby, 1802. How- ever, Kinzelbach (1978) stressed that western Palaearctic Stylops populations are in no way a homogeneous group and that great variation exists in the structures of female cephalothorax, and in the form of aedeagi in the males. Furthermore, Kinzelbach (1978) noted some kind of similarity in the morphology of Stylops parasitizing species of the same subgenus of Andrena, but he left the taxonomic value of this variation unsettled.

Host specificity of Stylops species is suggested to vary from one to several species of hosts. Bohart (1941) noted 21 "distinctive" species of Stylops from North America, about half of them having only one host species. In California, Linsley and MacSwain (1957) reported that S. pacifica Bohart is a common parasite of two Andrena species, but is unable to complete its life cycle on other host bees. In Germany, Borchert (1963) found that 1st instar larvae (triungulins) of Stylops parasitizing A. vaga differed in their morphology from the larvae parasitizing three other vernal Andrena species. This led him to suggest that there were two different species of Stylops in question. 
As is generally the case in Strepsiptera, the life cycle of Stylops involves hypermetamorphosis. A female produces even several thousand freeliving 1st instar larvae (Linsley \& MacSwain 1957), which the parasitised host bee leaves on food flowers of other bees. If a Stylops species is host specific, then a critical point during its life cycle would be to find the right host among several bee species visiting flowers with the 1 st instar larvae. The degree of flower specialization, especially in pollen collecting, varies among bees. Oligolectic bee species collect pollen within a few species of a genus or a family of plants, whereas polylectic species collect pollen from plants belonging to two or several families. Even though oligolectic bees usually forage for nectar from various kinds of flowers, the number of all food flowers is for oligoleges apparently much lower than for polyleges. For instance, Elfving (1968) recorded from finland on an average $( \pm S D) 14.9 \pm$ 10.4 and $31.7 \pm 21.8$ food plants for 13 oligo- and 12 polylectic and widely distributed Andrena species, respectively. Presumably, the successful completion of the life cycle of host specific Stylops is better in species parasitizing oligolectic hosts than in those parasitizing polylectic hosts. The aim of this report is to find if oligolectic Andrena species are more often infested by Stylops (stylopized) than polylectic ones, and by this means elucidate the host specifity of this group which has been problematic.

\section{Results and conclusions}

About half of all Andrena species in Finland and Germany are oligolectic, and among the species in which stylopization has been observed the proportions are 54 and 40 percent, respectively (Table 1). In Finland, stylopids have been recorded on about one third of the polylectic as well on the oligolectic species. The same proportions are higher in Germany, especially in polylectic species. However, the higher proportion may be simply caused by the larger material of Andrena from Germany, and the smaller material from Finland possibly does not include all rarely stylopized species.

Local proportions of stylopization may be highly variable, and Jensen (1971) noted even 18\% stylopized specimens in a large colony of oligo- lectic Andrena vaga Panzer in North Zealand in Denmark. In Finland, stylopids have been recorded on polylectic and oligolectic Andrena species (in collection materials) as follows (Pekkarinen \& Raatikainen 1973):

$\begin{array}{lcccc} & \text { Species } & \begin{array}{c}\text { Specimens } \\ \text { studied }\end{array} & \begin{array}{c}\text { Specimens } \\ \text { stylopized }\end{array} & \begin{array}{c}\text { Percentage } \\ \text { stylopized }\end{array} \\ \text { Polylectic } & 5 & 2247 & 97 & 4.3 \\ \text { Oligolectic } & 6 & 2713 & 50 & 1.8\end{array}$

The frequency of stylopized specimens is significantly smaller on oligolectic species $\left(X^{2}=25.4\right.$, $\mathrm{P}<0.001)$. This result indicates that oligolectic Andrena species are not stylopized more frequently than polylectic ones, and thus do not support several coexisting Stylops species with strict host specifity. If the same Stylops species parasitizes both oligo- and polylectic hosts, the large flower spectrum of polyleges possibly favours the dispersal of the 1st instars and the whole life cycle of Stylops better, than the lower spectrum of oligoleges.

Table 1. Numbers non-stylopized and stylopized (Stylops infested) on polylected (Pol.) and oligolectic (OI.) species of Andrena recorded in Finland and the former Western Germany. The material according to Pekkarinen and Raatikainen (1973), Kinzelbach (1978), Westrich (1990), Pekkarinen (1997) and unpublished notes by the late E. Valkeila.

\begin{tabular}{|c|c|c|c|c|c|c|c|c|}
\hline & \multicolumn{4}{|c|}{ Finland } & \multicolumn{4}{|c|}{ Germany } \\
\hline & Pol. & Ol. & $\Sigma$ & $\%$ ol. & Pol. & Ol. & $\Sigma$ & $\%$ ol. \\
\hline Non-styl. & 12 & 11 & 23 & 48 & 25 & 29 & 54 & 54 \\
\hline Styl. & 6 & 7 & 13 & 54 & 32 & 21 & 53 & 40 \\
\hline$\Sigma$ & 18 & 18 & 36 & 50 & 57 & 50 & 107 & 47 \\
\hline$\%$ styl. & 33 & 39 & 36 & - & 54 & 42 & 49 & - \\
\hline
\end{tabular}

Acknowledgements. Some records on stylopization originate from unpublished notes by the late Erkki Valkeila. The notes are preserved in the Department of Applied Zoology of the University of Helsinki. An unknown referee made several useful corrections to the manuscript.

\section{References}

Bohart, R. 1941: A revision of the Strepsiptera with special reference to the species of North America. - Univ. Calif. Publ. Entomol. 7: 91-160.

Borchert, H.-M. 1963: Vergleichend morphologische Untersuchungen an Berliner Stylops-L1 (Strepsipt.) zwecks 
Entscheidung der beiden Spezifitätsfragen: 1. gibt es an unseren Frühjahrs-Andrenen (Hymenopt., Apidae) mehrere Stylops-Arten und 2. gibt es Wirtsspezifitäten? -Zool. Beitr. N. F. 8: 331-445.

Elfving, R. 1968: Die Bienen Finnlands. - Fauna Fennica 21: 1-69.

Jensen, O. 1971: Iagtagelser over en koloni af stylopisered bier, Andrena vaga Panz., i Nordsjæland (Strepsiptera \& Hymenoptera, Apidae). (Observations on a colony of stylopized Andrena vaga Panz. in North Zealand.) — Entomol. Medd. 39: 90-95. (In Danish, with English summary.)

Kifune, T. \& Hirashima, Y. 1985: Nine new species of the genus Stylops (Strepsiptera: Stylopidae) parasitic on the genus Andrena (Hymenoptera: Andrenidae) of Japan (Studies on the Japanese Strepsiptera X). —Esakia 23: $45-57$.

Kifune, T. \& Maeta, Y. 1990: Ten new species of the genus Stylops (Strepsiptera, Stylopidae) parasitic on the genus Andrena (Hymenoptera, Andrenidae) of Japan
(Studies on the Japanese Strepsiptera XIII). — Esakia, Spec. Issue 1: 97-110.

Kinzelbach, K. 1978: Insecta Fächerflügler (Strepsiptera). — In: Tierwelt Deutschlands 65: 1-166. Veb Gustav Fischer Verlag, Jena.

Linsley, E. G. \& MacSwain, J. W. 1957: Observations on the habits of Stylops pacifica Bohart. - Univ. Calif. Publ. Entomol. 11: 395-430.

Luna de Carvalho, E. 1974: Contribuicão para o estudo dos Stylops da Peninsula Iberica (Strep. Stylopidae). - EosRev. Esp. Entomol. 48(1972): 301-365.

Mayr, E. \& Ashlock, P. 1991: Principles of systematic zoology. 2nd ed. - McGraw Hill, Inc., New York. 475 pp.

Pekkarinen, A. 1997: Oligolectic bee species (Hymenoptera: Apoidea) in northern Europe. - Entomol. Fennica 8. (In print.)

Pekkarinen, A. \& Raatikainen, M. 1973: Strepsiptera of Eastern Fennoscandia. - Not. Entomol. 53: 1-10.

Westrich, P. 1990: Die Wildbienen Baden-Württembergs I-I. 2nd ed. - Verlag Eugen Ulmer, Stuttgart. 972 pp. 